\title{
SOCIABILIDADES “NEGOCIADAS" NA FEIRA CENTRAL DE CAMPINA GRANDE/PB
}

\author{
Vanderlan Silva ${ }^{1}$
}

Tudo que tenho e o que eu sou é daqui, né? Assim, eu sempre tô orando, pedindo a Deus pra abençoar meus clientes. Porque é um ciclo, eles vêm me abençoam, eu já abençoo outra pessoa, e assim vai. Daqui a gente tira feira, daqui a gente tira nosso sustento. (Salete, feirante. 42 anos, 24 de feira)

A Feira Central de Campina Grande é um evento polissêmico no processo de formação da cidade e no conjunto das relações que cotidianamente são estabelecidas neste cenário social da urbe.

Neste analisamos os principais resultados de pesquisa ${ }^{2}$ realizada na feira central da cidade do interior paraibano. Nela, investigamos as sociabilidades construídas e vivenciadas entre feirantes e fregueses ${ }^{3}$.

Campina Grande, cidade lócus da pesquisa, tem quatrocentos e nove ${ }^{4}$ mil habitantes. E é a segunda cidade em importância econômica, política e demográfica do estado da Paraíba, estando situada a $120 \mathrm{~km}$ da capital do estado: João Pessoa. Marcada pela forte presença do terceiro setor na economia.

Historicamente a feira nasceu quando surgiu a cidade de Campina Grande em 1769. Desde o início da formação da cidade, a feira se fez presente, não como evento fortuito, mas como acontecimento perene que ajudou a moldar as faces sociais e econômicas da cidade paraibana. Durante o século XIX a feira foi palco de uma das principais revoltas populares da região nordeste durante o século XIX: Quebra-quilos. Revolta de feirantes e outros negociantes que se opunham às tentativas do governo imperial de unificar as medidas métricas, em substituição às pedras e outras unidades de medição até então utilizadas no comércio da cidade para medir/pesar as mercadorias.

\footnotetext{
${ }^{1}$ Universidade Federal de Campina Grande, Brasil. Email: vanderlansilva@uol.com.br ORCID id: https://orcid.org/0000-0003-4299-0711

2. A pesquisa contou com apoio financeiro do Conselho Nacional de Pesquisa (CNPq), através da concessão de bolsas de pesquisa e foi realizada entre os anos de 2017 e 2019. Monalisa Castro, Anna Amélia e Luiz Filho participaram da pesquisa na condição de auxiliares de pesquisa.

3. O Dicionário Houaiss considera como feirante tanto quem vende quanto quem frequenta a feira. Todavia, nos limites deste trabalho nós procuramos diferenciar os que compram, nominando-os de fregueses, e de feirantes aqueles que vendem no lugar.

4. População estimada para o ano de 2020. Fonte: IBGE Cidade. Disponível em
} https://cidades.ibge.gov.br/brasil/pb/campina-grande/panorama . Acesso em 24 de maio de 2020. 
Embora seja indiscutível a importância da feira no processo de formação da cidade paraibana, nosso interesse em tomá-la como locus de pesquisa não reside num olhar voltado para o passado, mas na importância que a mesma assume no presente. As dimensões geográfica e demográfica demonstram o lugar de relevo que a chamada Feira Central $^{5}$ ocupa no seio da cidade. Encravada em pleno centro, a Feira Central ocupa uma área de $75.000 \mathrm{~m}^{2}$, formada por oito ruas, nas quais quatro mil e quatrocentos pontos $^{6}$ de negócios e mais dez mil feirantes fazem negócios com dezenas de milhares de fregueses que semanalmente se deslocam até a feira à procura de produtos tradicionais e modernos, mas também em busca de lazer, de conversação, de tomar uma cachacinha com amigos, de comer uma rabada, uma buchada ou ainda de tomar café com tapioca.

Esses números fazem da Feira Central de Campina Grande uma das maiores feiras livres do Brasil. Em 2017 ela foi reconhecida pelo Instituto Brasileiro de Patrimônio Histórico Artístico e Nacional (IPHAN) como patrimônio cultural do Brasil.

A escolha da Feira Central como palco das investigações se justifica por sua importância nas interações sociais da urbe paraibana. Ao longo das últimas décadas surgiram várias outras feiras permanentes em bairros periféricos da cidade, que funcionam em lugares fixos, em dias regulares, uma vez por semana, com infraestrura estabelecida, além de feiras temáticas e ambulantes, que circulam pela cidade ao longo da semana, tal como se observa em várias outras cidades do país. A Feira Central, contudo, funciona de segunda a sábado, iniciando-se ao alvorecer e indo até o final da tarde. O sábado é o dia da grande feira, ou seja, o dia de maior movimento de pessoas e de volume de negócios e no qual todas as bancas estão abertas, funcionando a pleno vapor das negociações ali estabelecidas.

Muitos dos feirantes que negociam na Feira Central da cidade, bem como compradores são oriundos de várias cidades do interior da Paraíba e de alguns dos estados vizinhos, a exemplo de Rio Grande do Norte e Pernambuco. Essa abrangência demonstra o raio de ação e influência que a feira de Campina Grande exerce em parte

\footnotetext{
${ }^{5} \mathrm{O}$ surgimento de várias feiras livres ao longo do século XX fez com que a principal feira da cidade passasse a ser comumente referida como Feira Grande ou Feira Central, tal como utilizamos nesse texto. Entre algumas dessas feiras surgidas em bairros da cidade, destacamos a Feirinha de Bodocongó, Feira do Catolé, Feira da Liberdade, Feira das Malvinas e Feira da Prata.

${ }^{6}$ Dados oficiais fornecidos pela gerência da Feira Central de Campina Grande-PB.
} 
considerável da região nordeste do país. Não por acaso, ela é classificada por uma das principais estudiosas de feiras como "regional" 7.

\section{A construção do campo de pesquisa}

Ao iniciarmos a pesquisa, a feira já era um lugar familiar, pois há anos a frequentávamos na condição de fregueses. Todavia, como a maioria daqueles que semanalmente fazem suas compras ali, tínhamos itinerários previamente estabelecidos, feirantes de referência nos quais fazíamos nossas compras, onde entabulávamos diálogos, guardávamos nossas sacolas, etc. Ao iniciar a pesquisa, procuramos ampliar nossos itinerários, circular por caminhos até então desconhecidos no interior da feira e conhecer outros feirantes e fregueses. Para isso, inicialmente, realizamos inúmeras incursões etnográficas em dias e horários diferentes para treinar o olhar e poder melhor observar as minuciosidades do cotidiano de feirantes e frequentadores naquele cenário. Procuramos identificar gestos, gritos, vivências, relatos, narrativas, práticas de lazer, conversações, trabalhos, estratégias de arrumação dos produtos, formas de atração de clientes, etc. Fizemos um mapeamento para identificar as ruas e os respectivos setores nos quais os produtos são comercializados, a exemplo das verduras, carnes, peixes, queijos, doces, roupas, temperos, produtos eletrônicos, raízes, galinhas (vivas e abatidas), cereais, laticínios, tabaco, flores, móveis, artigos religiosos, couro e cerâmica, cestos de palha, ferragens etc. Esses "setores" especializados na venda desses produtos são também chamados de feiras: feira de peixe, de verduras...

As várias incursões etnográficas realizadas ao longo da pesquisa foram importantes para estabelecer maior familiaridade com o espaço geográfico da Feira Central e, por conseguinte, com os feirantes e fregueses. Junto aos primeiros realizamos vinte e uma entrevistas gravadas a partir de roteiro semiestruturado, sendo doze entrevistas com pessoas do gênero masculino e oito ${ }^{8}$ com o gênero feminino. Entrevistamos ainda dez fregueses, sendo quatro homens e seis mulheres, seguindo igualmente roteiro previamente estabelecido. Além desses personagens, entrevistamos ainda o administrador da Feira Central em duas ocasiões.

\footnotetext{
${ }^{7}$ SATO, Leny. Feira Livre. Organização, trabalho e sociabilidade, São Paulo: Edusp, 2012, classifica a feira de Campina Grande como regional.

${ }^{8}$ A feirante Salete foi entrevistada em duas ocasiões, em razão do papel de liderança que a mesma exerce entre os seus congêneres.
} 
O roteiro de entrevistas nos serviu como "ponta-pé-inicial” para as "conversas' com feirantes e fregueses. Em muitas ocasiões as entrevistas se desenvolveram muito além do que tínhamos planejado inicialmente.

Como em quase toda pesquisa etnográfica, os muitos diálogos estabelecidos e situações observadas, conversações produzidas na presença do pesquisador e tantos outros eventos testemunhados em campo acabaram por nos ajudar a ampliar as percepções sobre o universo social da feira. O uso das entrevistas formais (gravadas) se deu não apenas pela importância do acesso posterior ao registro formal das informações colhidas junto a feirantes e fregueses, mas também por aquilo que Minayo observa:

A possibilidade de a fala ser reveladora de condições estruturais, de sistema de valores, normas e símbolos (sendo ela mesma um deles) e ao mesmo tempo ter a magia de transmitir através de um porta-voz, as representações de grupos determinados, em condições históricas, socioeconômicas e culturais específicas. (Minayo, 2004: 109-110).

As entrevistas com os feirantes foram realizadas depois de processos de aproximação feitos durantes vários dias. As entrevistas foram gravadas em pleno vapor das atividades. Em algumas situações entrevistas foram momentaneamente suspensas para atendimento a clientes, sendo retomadas na sequência.

Muitos foram os feirantes que mesmo depois de "conhecidos" e aos quais foram apresentadas as razões da pesquisa, negaram-se a gravar conversas. Na maioria dos casos, a justificativa apresentada foi a "falta de tempo". Claro, que como podemos supor, essa era foi uma maneira cordial de expressar a falta de vontade, a desconfiança, entre outros temores com a figura do pesquisador e, por conseguinte sobre os possíveis e imaginados usos que poderiam eventualmente ser feitos da entrevista.

Em duas situações específicas, as negativas se mostraram reveladoras das desconfianças sobre quem era o pesquisador e sobre o que pretendia, mas também, paradoxalmente, de novos contatos. No primeiro, um vendedor de queijo, sempre solícito ao diálogo nas muitas vezes que entabulávamos conversas 'informais', quando convidado para gravar a conversa (entrevista), justificou que não tinha tempo, que tinha muita gente para atender e que preferia outro dia com menos movimento. Até que certo dia, ao ser indagado sobre o caminho para se chegar à sede da administração da feira, ele assumiu o lugar de indagador, nos questionando se estávamos trabalhando para o administrador. Embora as conversas com ele tenham persistido em outras ocasiões, o 
dia com disponibilidade de tempo para dar entrevista nunca chegou durante o tempo em que permanecemos no campo de pesquisa.

O segundo exemplo é de um feirante de produtos religiosos. Frente aos inúmeros convites pra gravarmos a conversa, ele pedia para remarcarmos, mesmo quando o dia e horário já haviam sido indicados por ele. Todavia, ele acabou funcionando como um intermediário junto a outros feirantes, pois indicou vários outros feirantes à pesquisa.

As entrevistas com os fregueses foram realizadas de maneira itinerante, enquanto esses realizavam suas compras, escolhendo mercadorias que lhes pareciam apropriadas aos seus gostos. A itinerância foi um dos elementos de dificuldades ao longo do processo de realização das entrevistas com os fregueses, pois circular pela feira livre não é uma tarefa fácil, mesmo para quem tem familiaridade com lugar, pois cada itinerário traçado se compõe a partir de múltiplos desafios para os transeuntes na condição de fregueses precisam enfrentar ao tracejarem ruas, vielas, becos. Como bem destaca Barbosa,

É impossível andar pela feira sem se abaixar, fazer curvas bruscas e parar constantemente. $\mathrm{O}$ trânsito é muito complexo e o andar é sempre desviante. É necessária certa ginga para passar pelos espaços que se imbricam. Andar pela feira leva o corpo a uma nova aprendizagem em relação à movimentação, que, nesse lugar precisa levar em conta a extrema proximidade com outros corpos (Barbosa, 2011:4)

Corredores estreitos, poças d'água, carroceiros que fazem transporte de mercadorias para fregueses roçando seus "carros de ferro" nas pernas de transeuntes, bancas de verduras que "invadem" os espaços de circulação dos pedestres/fregueses e das quais é preciso se desviar são alguns dos obstáculos que precisam ser enfrentados. Em alguns casos, acompanhamos fregueses até o ponto do ônibus, nas adjacências da Feira Central, para dá continuidade às entrevistas. As descrições de tais circunstâncias desenham com proximidade os desafios enfrentados na realização de tais diálogos.

Evidentemente, tal como no caso dos feirantes, para cada informante entrevistado, muitos outros fregueses nos disseram não, motivados pelas muitas razões que quase sempre povoam as desconfianças de quem é convidado para ser entrevistado em plena feira livre, na correria das compras, em meio à multidão e as inquietações e tensões que "fazer a feira" produz em cada freguês. Evidencie-se ainda, que diferentemente de muitos feirantes, que tiveram oportunidade de nos ver com frequência 
durante a pesquisa, e até conversar, os fregueses foram abordados por um 'estranho' que se apresentava como pesquisador, em circunstâncias nas quais estavam concentrados nas compras a serem feitas (e todo o processo que o envolve), e que, em caso de aceitação da entrevista, precisavam circular pelos espaços da feira acompanhados por essa recém-chegada companhia, sobre a qual havia muito mais dúvidas do que certezas.

Os desafios da realização da etnografia em itinerância nos revelaram não apenas dificuldades, desconfianças, mas também nos levaram a conhecer muitos dos trajetos feitos pelos fregueses na feira, adentrando ruas e becos. Assim, pudemos conhecer muitas das maneiras de se estabelecer negociação com os mais distintos feirantes; em quais circunstâncias, dias e horários é possível pechinchar e quais feirantes são mais receptivos ou fechados às negociações dos valores; como escolher os vários tipos de mercadoria etc.

Realizada a partir de muitos movimentos de interação entre os nossos interlocutores nos seus cotidianos e afazeres, e entre eles e nós, a pesquisa se produziu num universo no qual múltiplas possibilidades emergiram das mais variadas formas. E, tal como observou o antropólogo:

O campo não é uma coisa, não é um lugar, nem uma categoria social, um grupo étnico ou uma instituição. É talvez tudo isso, segundo o caso, mas é antes de tudo um conjunto de relações pessoais com as quais "aprendemos coisas". "Fazer pesquisa de campo" é estabelecer relações pessoais com quem não conhecemos anteriormente, junto de quem chegamos um pouco na marra. É então preciso convencer da lisura de nossa presença, pelo fato de que eles nada têm a perder mesmo se também não têm grande coisa a ganhar, sobretudo que eles não correm nenhum risco. As relações podem ser harmoniosas com uns, conflitivas com outros. Nada de conhecimento íntimo de um tema sem conhecimento das pessoas. Logo, não há saber sem relações (Agier, 2015: 34).

Os desafios e 'descobertas' na Feira Central se produziram em um campo cujos dados não estavam a nossa espera para serem colhidos. Ao contrário, eles precisaram ser construídos a partir das relações que estabelecemos com feirantes, fregueses e administração municipal da feira.

Os personagens abordados nesse texto não são homogêneos. E essa inomogeneidade está diretamente vinculada às relações estabelecidas nos espaços sociais da urbe. A Feira Central, tal como a cidade, é um espaço multifacetado, vivido e praticado pelos indivíduos e grupos de distintas maneiras. Lugar fragmentado em permanente processo de transformação, de (re) significações e de atores que 
cotidianamente atuam sobre seu solo físico e social. No limite, a Feira Central não é una, ao contrário, ela é diversa em sua configuração. Os vários setores que a compõem "parecem propor" peculiaridades/formas distintas de relações aos seus sujeitos. A denominação atribuída a cada um serve como indicativo de diferenciações: feira de peixe, feira de cereais, feira de carnes, feira de verduras, feira de queijos e doces, feira de roupas etc. As sociabilidades que aí são configuradas cotidianamente podem ser chamadas de sociabilidades do "homem simples", talvez porque na feira como alhures,

Por entre ou ao redor dos usos hegemônicos, de espaço de acumulação capitalista, se reproduz o espaço banal, lócus da reprodução da vida cotidiana, animada por uma infinidade de pequenos agentes anônimos, seja em busca de formas de sobrevivência material, seja na busca da cidade-obra. (Lefebvre (1991:68).

E, como bem ressalta (Vedana 2013:23), "o feirante ocupa um lugar na rua, fazendo dela outro lugar, em meio à circulação de anônimos, e transforma esse espaço de intimidade e sociabilidade, de encontros, trocas..."

\section{Odores, cores, sons e interações sociais na Feira Central}

Aos olhos de um não habitué da Feira Central de Campina Grande, essa pode parecer um caos, uma bagunça, dada as múltiplas formas de organização, de interações, mas também por causa dos diversos odores ali produzidos, aos sons de músicas que tocam nos aparelhos de som, aos anúncios de mercadorias; aos gritos de vendedores e vendedoras que perfomatizam para atrair as atenção dos potenciais compradores. Tal pluralidade também é formada pelas cores presentes na Feira Central, resultado da junção de milhares de pessoas que por ali transitam com suas roupas das mais distintas estampas e tonalidades e pelo colorido dos produtos naturais expostos nas bancas de verduras, leguminosas e frutas, de onde exalam cheiros que suscitam a imaginação degustativa de muitos.

Há, notadamente, variação de tons entre os chamados "setores" da feira. A 'feira de frutas e verduras', situada na entrada principal, funciona a céu aberto, sempre muito cheia de compradores que na chegada ou na partida param para comprar produtos frescos. Nos primeiros duzentos metros da rua, circulada de ambos os lados por bancas de frutas e verduras, os fregueses se amontoam em frente às bancas para perguntar, 
conversar, comprar. O constante movimento da multidão que por ali circula e interage, ilustram bem a importância da feira para a cidade.

O colorido diminui na medida em se penetra nos demais setores da feira. Nas feiras de carne e de ferramentas, assim como na feira de peixe predominam o 'tom pastel'. Ali os gritos de feirantes são menos evidentes e a pluralidade dos odores se reduza sensivelmente. Neles, especialmente no setor das carnes, as relações parecem mais sisudas, diretas, com menos espaços para as conversações que encontramos com facilidade no setor de verduras/frutas e na feira de queijo.

O conjunto das relações sociais estabelecidas na Feira Central está estreitamente vinculado aos valores e práticas que ajudam a 'moldar' as formas de interação entre os indivíduos e grupos sociais no cotidiano. Não por acaso, as relações entre vendedores de carne e entre esses e seus clientes parecem se configurar com base nos lugares sociais ocupados pelos marchantes na hierarquia das relações políticas e econômicas no seio da Feira Central. Em várias entrevistas realizadas com feirantes, bem como com o administrador da Feira Central, esses destacaram o papel de relevo que tal subcategoria exerce nos destinos da feira.

Em meio a tantas configurações das mais variadas ordens, a feira também é construída cotidianamente como lugar dinâmico, no qual afloram as situações de imprevisto, de improviso, do acaso e do pitoresco. Tal como destaca o historiador.

\begin{abstract}
A feira quase sempre se faz em lugares públicos e se caracteriza pelo aglomerado de pessoas, pela multiplicidade de vozes, de pregões, de falas, de ditos que se misturam, pela multiplicidade de vozes, se confundem e terminam por gerar uma verdadeira algaravia de vozes. Ela também remete à multiplicidade de apelos em torno das distintas mercadorias que se tenta vender. Os diferentes anúncios que aí se fazem significam a colocação no mercado dos mais disparatados artefatos para serem consumidos (Albuquerque Jr. 2013: 24)
\end{abstract}

A visão do feirante Gilvan esmerada durante ao longo de sua existência de 31 anos, sempre ligada à feira, pois pertence à terceira geração familiar que ali negocia, destaca as cores e estampas do tecido cultural que formam a Feira Central da cidade.

A feira significa diversidade, tem de tudo aqui, você consegue de tudo, e de todo tipo de gente, de interior de cidade pequena, dos sítios, você tem o contato com todo mundo e também, a diversidade de produtos, tem pequenos agricultores, tem pequenos comerciantes, comerciante familiar, tem uma diversidade muito grande. Então o que eu vejo da feira é diversidade. 
Para muitos dos que buscam o exótico, seja entre os turistas que regularmente visitam a Feira Central em caravanas ou como "lobos solitários", sejam ainda entre os moradores da cidade e do seu entorno que se veem 'forçados' a ir até lá em busca de alguma mercadoria difícil de ser encontrada em outro lugar, ela se apresenta com aspectos caóticos, antiquados, sinônimo de atraso e de anti-moderno. Lugar onde os corpos se roçam involuntariamente frente à multidão que circula pelas ruas, becos e por entre as bancas da feira; onde o barulho de gritos de vendedores que procuram chamar atenção para os seus produtos ou de carroceiros que tentam abrir espaços entre os transeuntes para acompanhar seus clientes, conduzindo suas compras; lugar no qual eclode algaravia de centenas de pessoas que falam ao mesmo tempo, bem como do ronco de motos, cujos condutores se aventuram por entre as pessoas para comprar, pegar ou entregar alguma mercadoria.

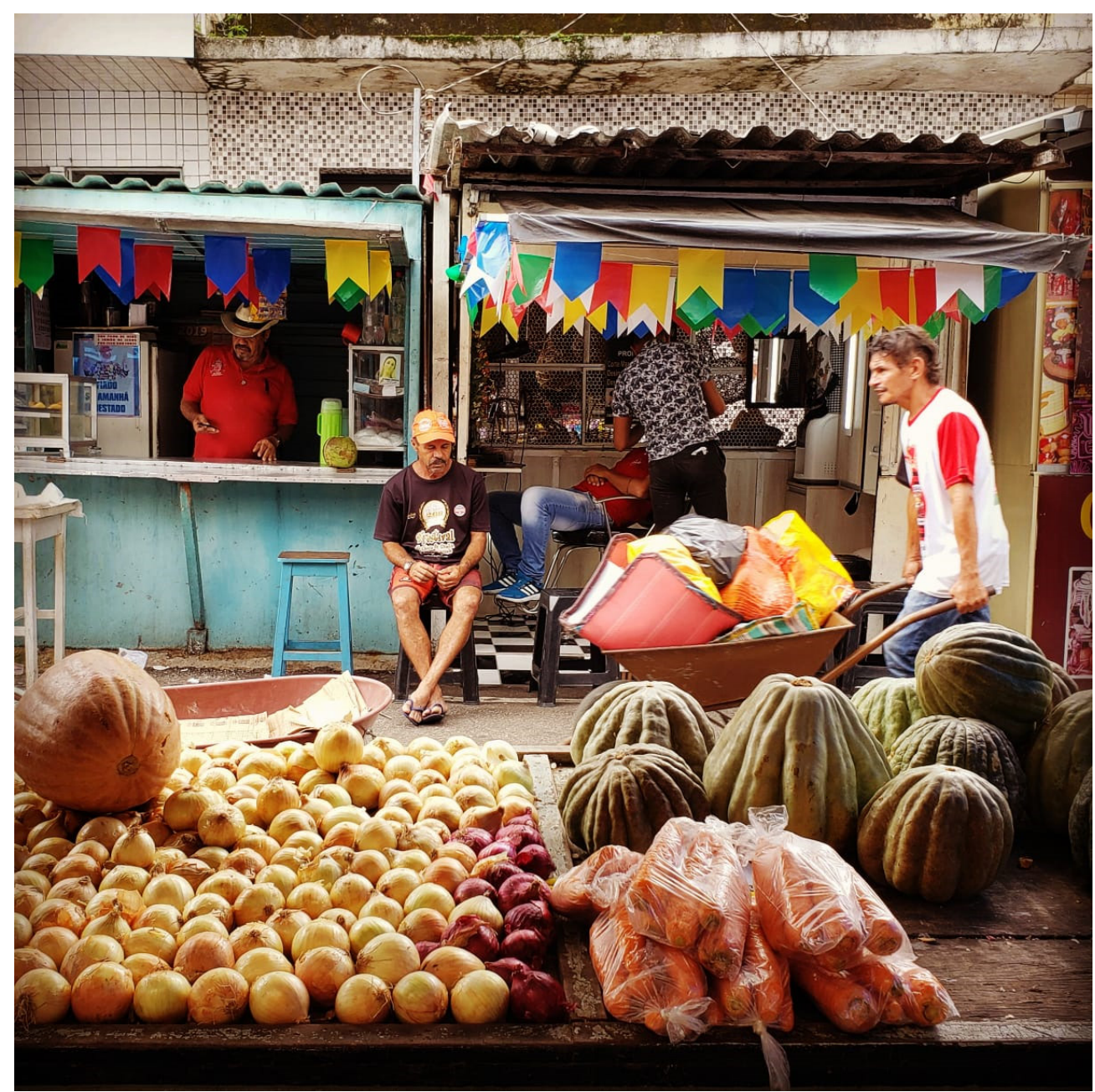

Cena do cotidiano na Feira Central. Vendedor de Lanches, barbeiro, carroceiro e clientes. Créditos: Franciscarlos Diniz. 
Nesse cenário e diante de tal olhar, a Feira Central emerge como uma "bagunça organizada" que parece estranha, inabitual ao olhar acostumado à lógica de organização da modernidade, dos pontos de comércio ordenados segundo a impessoalidade dos supermercados, onde não há espaço para o imprevisível nas negociações, onde nada pode ser degustado antes de ser comprado. Ao contrário do caráter hermético que predomina nos supermercados, as lógicas de interação na Feira Central de Campina Grande se constituem a partir de possibilidades que são sugeridas de acordo com a relação entre freguês e feirante. Um antigo e 'bom' freguês tem acesso aos melhores produtos reservados pelo feirante, que sabe que tal gesto ajuda a preservar uma relação construída durante anos.

Num dos dias de pesquisa testemunhamos uma conversar entre um_vendedor de peixe e um cliente habitual. Este último havia viajado ao exterior sem avisar ao feirante, com o qual tinha pendências financeiras, já que acertava suas compras sempre ao final de cada mês. Frequentador assíduo da banca, sempre que lá chega já encontra sua mercadoria devidamente separada pelo feirante. Na ocasião mencionada, ao explicar ao vendedor que tinha passado dois meses ausentes, o feirante the respondeu, rindo, que imaginava que algo assim tinha acontecido e que não tinha se preocupado, pois sabia que ele retornaria para novas compras.

O exemplo a seguir, assim como o do freguês viajante, ilustra bem os tipos de relações que se estabelecem entre feirantes e fregueses, baseados em práticas e valores que estendem para além das relações comerciais estabelecidas entre ambos. Mayra, 66 anos, é compradora de produtos na Feira Central desde quando era criança, trazida à feira por sua mãe. Ela relata que certa vez sua irmã que mora em São Paulo, ao acompanha-la à feira ficou chocada, pois ela ia comprando e deixando as sacolas com compras aos cuidados de uma feirante conhecida, evitando assim andar com peso excessivo, fato que fez com que sua irmã lhe indagar se ela "era doida" em confiar as sacolas aquela feirante.

A relação de confiança entre Mayra e seus amigos feirantes criam até mesmo a possibilidade de, na falta de dinheiro, pedir emprestado a esses: “Às vezes eu passo na feira e não estou com dinheiro, mas quero comprar uma coisa, peço dinheiro a um amigo compro e vou embora". 
Mayra, assim como os demais fregueses sabem que toda relação cria a necessidade de interação, da reciprocidade. Ao ser indagada sobre se tinha fidelidade a alguns feirantes, ela não titubeou na reposta: “Tenho, tenho vários. De queijo, de verdura, de legumes". Não é difícil imaginar onde Mayra costuma deixar suas sacolas nem a quem costuma pedir dinheiro emprestado quando precisa complementar suas compras.

Perla, freguesa de 50 anos, que há pelo menos 30 anos frequenta a Feira Central destaca igualmente a existência de fidelidade a alguns feirantes:

\begin{abstract}
Olha como são muitos anos, a gente compra um produto em um lugar e a pessoa, e você ver que o produto é bom, foi bom atendido, que é de qualidade, você tende a voltar. Então a gente já tem aqueles pontos, já entra alí uma afinidade, você já conhece o nome do vendedor e o vendedor já lhe reconhece, forma-se um vínculo, você já sabe o lugar que você vai. Já vou assim de olho fechado. Cria até um laço de amizade não
\end{abstract}

A confiança estabelecida entre cliente e feirante é fruto de ações que se desenvolvem ao longo do tempo e requer sempre atenção para a manutenção do contrato social que eles estabelecem. As falas de alguns feirantes são reveladoras dos caminhos que percorrem na construção das relações com os clientes. Segundo Siqueira, comerciante de 38 anos e há 6 trabalhando na Feira Central, "A gente sem os clientes não é nada, tem que ter boa clientela boa e eles tem que ter confiança no produto que a gente vende, senão a relação não dá certo". O encontro entre quem vende e aquele que compra se dá, inicialmente, intermediado pela negociação de mercadorias. E esse elemento primário da relação permanece como importante na relação estabelecida. Manoel, jovem comerciante Manoel, de 32 anos e há 20 atuando como comerciante na feira observa que "preza muito isso, bom relacionamento em todos os sentidos, principalmente no comercial". Jeremias, de 75 e há 45 sendo feirante, pensa de maneira semelhante sua relação com os clientes. Ele afirma "Se não atender bem, perde o cliente, não volta mais. Já entrou cliente aqui e disse - Eu vim comprar porque o senhor atende bem, o senhor é alegre."

A construção de tais relações com os clientes seguem percursos imprevistos, cuja condução depende das ações e reações que cada um dos interlocutores envolvidos pode assumir em cada evento. Jeremias, anteriormente citado, observa que existem clientes que "dão um pouco de trabalho". Cibele, comerciante de 78 anos, e há 53 anos 
trabalhando na feira como negociante de verduras e legumes, também reconhece as dificuldades de lidar com muitos clientes "abusados", frente aos quais ela observa que costuma ficar "calada" quando esses reclamam excessivamente.

Muitas das relações que os mais de dez mil feirantes estabelecem com os inúmeros clientes cotidianamente são fortuitas, passageiras, efêmeras e se 'reduzem' às atividades comerciais. Outras, contudo, nascem nesse momento e se estendem para além das trocas comerciais, mesmo que essas persistam. $\mathrm{O}$ exemplo da freguesa que deixa suas sacolas numa das bancas e eventualmente pede dinheiro emprestado demonstra bem a extensão das relações. Salete, comerciante de queijos de 42 anos, há vinte quatro trabalhando na feira destaca que "a maioria dos meus clientes é gente tudo amiga, eles são meus psicólogos e eu sou o psicológico deles”. Benício, feirante de 32, há 18 trabalhando na feira afirma que tem "uma relação grande com clientes, com pessoas próximas, como se fossem amigos. Os clientes bem próximos."

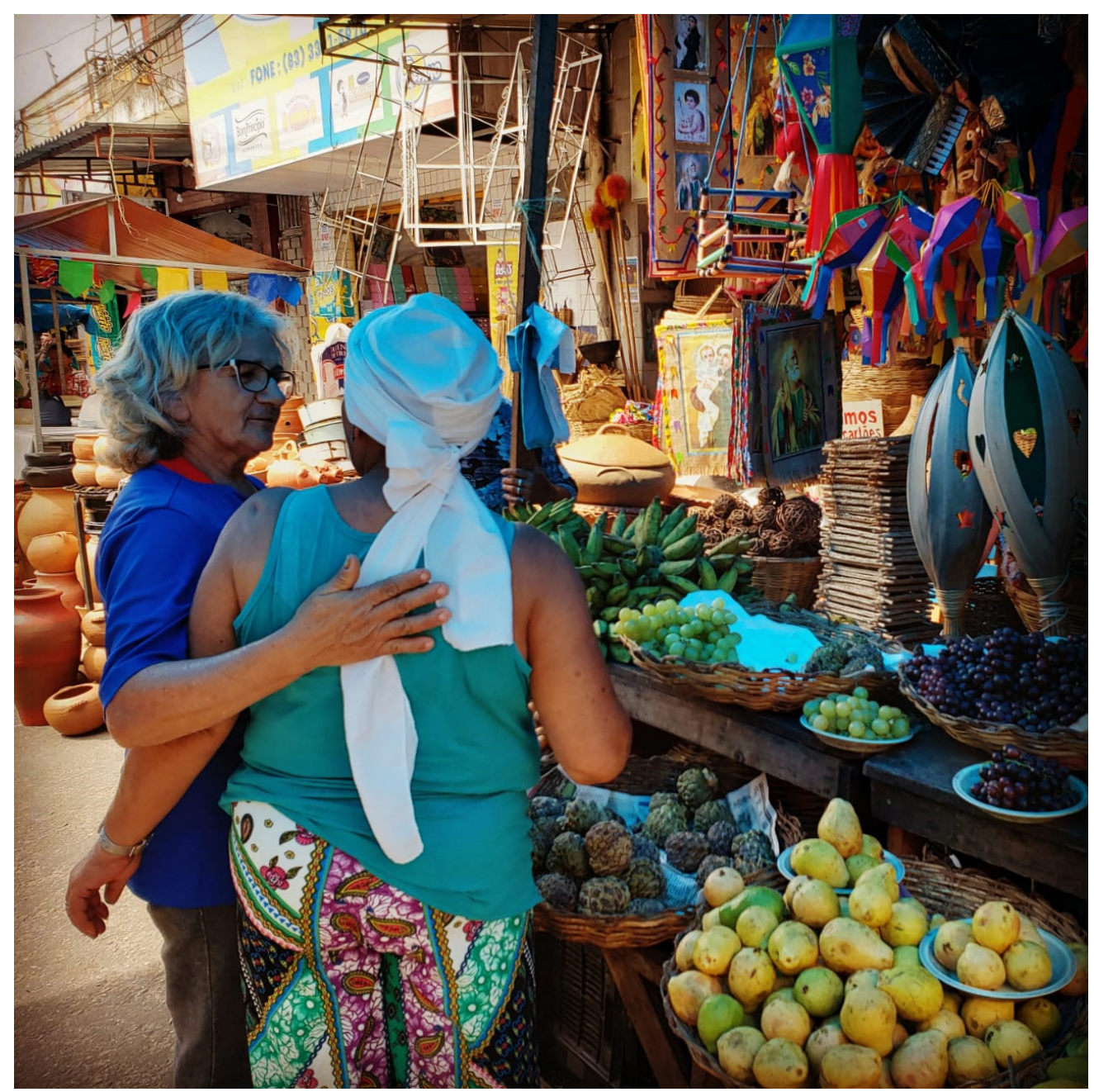

Cliente e feirante se cumprimentam com um abraço na feira. Créditos: Fraciscarlos Diniz 
Assim, percebemos que os atos de comprar e comercializar na Feira Central estão imbuídos de significados que podem se estender para além da "razão prática" e mercantilista que dá origem aos primeiros contatos entre feirantes e fregueses.

\section{Ser feirante. Fazer-se freguês: Herança e aprendizado}

A arte de comercializar na Feira Central de Campina Grande é resultado de processos sociais que se desenvolvem ao longo de muitos anos. Na pesquisa em tela, dos vinte feirantes entrevistados, dezesseis deles começaram suas atividades comerciais por influência de parentes que negociavam na localidade. A grande maioria dentre eles foi trazida para o ambiente da feira ainda quando eram crianças e em muitos casos assumiram a titularidade da banca na adolescência. "Desde quando nasci. Eu acho que quando eu nasci já me trouxeram pra feira aqui e comecei a trabalhar, eu acho que eu tinha 10, 12 anos de idade", afirma Everton, feirante de 46 anos. A feirante Salete, mencionada anteriormente, revela trajetória semelhante à de Everton, ao afirmar que chegou à feira “Através da minha mãe, porque a minha família já vivia aqui com doce, né? fabricava e vendia aqui na feira, aí surgiu a oportunidade do ponto. Ela perguntou se eu não queria. Eu disse que queria. Aí pronto. Aí fiquei.”

Ao longo das trajetórias de cada feirante, muitos são os desafios que eles têm que enfrentar nas relações cotidianas que estabelecem com os mais distintos atores sociais. Jeremias, feirante de 45 anos, há 25 trabalhando na feira, e igualmente referido em linhas anteriores, indica alguns dos aprendizados pelos quais precisou passar para melhor lidar com os desafios do comércio na feira.

Tudo se começa, ninguém chega lá de cima pra baixo não. Tudo é de baixo pra cima, tudo tem um começo, eu cheguei aqui na feira, eu num tinha nada, hoje eu dou graças a Deus, termos materiais, espirituais. Porque a maior riqueza são as coisas espirituais, a maior riqueza, através do espiritual você vai conseguindo os materiais, através os espirituais você vem seguindo o caminho certo, a obediência né? E crendo né? Com paciência, porque aqui você tem que ter paciência. Se você entrar no comércio, se você num tiver paciência você num passa um mês, viu.

O "desenvolvimento espiritual" na fala de Jeremias surge como sinônimo de refinamento psicológico, autocontrole nas relações com um vasto e diverso público que frequenta a feira e com o qual é preciso ter "jogo de cintura", tolerância, paciência para lidar com as demandas apresentadas. 
Aprender a lidar com as pessoas nas relações cotidianas na feira faz parte de processos que os feirantes encaram durante toda a trajetória como comerciantes. Mesmo que a experiência acumulada ao longo dos anos seja um facilitador, novos desafios surgem permanentemente no seio das relações ali estabelecidas. O surgimento de novas demandas por mercadorias e clientes com desejos específicos, além da publicidade e procura através das redes virtuais, a exemplo do Instagran, Facebook e Whatsap são alguns dos desafios que se apresentam aos feirantes mais apegados às formas tradicionais de comercializar no interior da Feira Central.

Tais processos de socialização (Berguer \& Luckman, 1994) e de interação simbólica (Blumer, 2013) são comuns também aos clientes que aprendem, pouco a pouco, como se "comportar bem na feira". E, interagir bem implica, entre muitas outras possibilidades, em saber responder as propostas, os gracejos, assédios e propostas dos feirantes; escolher as mercadorias; responder aos agrados; olhar com discrição para as mercadorias nas bancas, sem parecer excessivamente interessado e assim poder melhor negociar o preço dos produtos; pechinchar sem parecer avarento. Saber disso não garante proteção contra conflitos, incompreensões, ao contrário, até pode estimulá-los, contundo, ter a compreensão sobre como podem ser estabelecidas as relações na Feira Central funciona como espécie de guia a partir do qual traçam caminhos iniciais frente a seus interlocutores na feira.

Os seres humanos interpretam ou definem as ações uns dos outros, em vez de simplesmente reagir a elas. Sua reação não se dá diretamente às ações dos outros, ao contrário, é baseada no significado atribuído a essas ações. Assim, a interação humana é mediada pelo uso do símbolo, pela interpretação ou pela atribuição de significado às ações dos outros. (Blumer, 2013: 76)

Os muitos personagens da Feira Central, entre os quais estão feirantes e fregueses, não interpretam as ações a partir do acaso, mas a partir de referencias sociais, entre os quais o universo da feira funciona como semióforo (Chauí, 2000), uma moldura social.

\footnotetext{
A organização é a moldura no interior da qual as unidades de ação desenvolvem suas ações. Os traços estruturais, como cultura, sistemas sociais, estratificação social ou papéis sociais, definem as condições para sua ação, mas não a determinam. A organização social só entra na ação na medida em que modela as situações nas quais as pessoas agem, e na medida em que fornece conjunto fixos de símbolos utilizados por elas para interpretar as situações. (Blumer, 2013: 87)
} 
No dia a dia das relações entre fregueses e feirantes, o universo social da feira emoldura as relações entre ambos, sem, contudo, determiná-las, como bem observou o estudioso estadunidense. Observe-se que não há um acúmulo ideal possível que permita a um freguês ou freguesa dominar todos os códigos de conduta presentes na Feira Central, pois a experiência de cada frequentador por mais vasta que seja, será sempre parcial. Ninguém frequenta, interage ou compra em todos os setores da feira.

Em meio às indeterminações das relações, sinônimos de imprevisibilidades, surgem os conflitos, esses fenômenos que, como bem delineou Simmel (1995), podem assegurar a possibilidade de continuidade das relações estabelecidas a partir de novas perspectivas, assim como podem, eventualmente, destruí-las.

A irmã 'paulista' que reprimiu a freguesa por ter deixado as sacolas de compra aos cuidados de um feirante amigo mostra bem como as experiências e tipos de relações estabelecidas variam e como são interpretadas de maneiras diversas. Na maioria das situações vivenciadas por nossos interlocutores 'fregueses' o processo de interação na feira começou quando eram crianças levadas pelos pais.

Curioso é observar as justificativas que muitos dão para continuar a frequentar a Feira Central, mesmo quando, aparentemente poderiam ter 'maiores facilidades' se fizessem as compras nos mercadinhos ou nas feiras livres próximas de suas residências. A variedade e o preço das mercadorias surgem como as principais justificativas para que continuem a fazer suas compras na feira. Quando cotejamos tais justificativas com outros momentos das entrevistas, percebemos que as mercadorias e os preços emergem como evidências primárias da relação dos fregueses com a Feira Central de Campina Grande. "Era meu pai que trazia nós, eu mais meus irmão. Era uma festa só. Vinha tudo pra cá, comprava as coisas, nós ficava aqui até bem de tarde. Meu pai gostava de tomar um negocim, aí nois comia aqui, fazia a feira e ia pra casa." Ao setenta e dois anos, e residindo longe da feira, Cícero continua a frequentá-la e produz um comportamento que via outrora. "A feira é bom demais. Aqui eu vem...compro minhas coisinha bem baratinha e ainda vou tomar um negocim na barraca (muito riso). Tem coisa miô?

- E esse menino que está com o senhor?

- “É meu netim, vem todo sábado mais eu.

- Por que o senhor o traz?

"Cícero: é pra mode aprender a gostar da feira (risos)". 
As ações de Cícero demonstram a importância do cenário social da feira em sua vida. Ele surge como uma ponte que liga as gerações anteriores e posteriores, pai e neto, respectivamente. De algum modo ("tomar um negocim") Cícero rememora, reaviva, imita, reproduz as ações do seu pai. De muitas maneiras reinventa sua vida, dá sentido à sua existência e ajuda a configurar sentidos à vida de seu neto, que o vê tomando um "negocim" e rindo, feliz, por estar na feira.

Gilvan, feirante já abordado anteriormente percebe bem o que se passa com Cícero e tantos outros fregueses e freguesas que herdaram o costume de frequentar a Feira Central de seus pais "Eu vejo muita gente que traz o neto, às vezes tem gente aqui que compra aqui já por causa do pai, que já vem dos avós, e continua mantendo essa tradição. Vira mais ou menos uma rotina, um vício."

A Feira Central existe para além das relações comerciais. Como instituição social ela é cenário de encontros entre amigos; é lugar praticado por diversas classes sociais da cidade de Campina Grande e de municípios circunvizinhos. Isso exprime bem a afirmação do sociólogo alemão, segundo a qual

\begin{abstract}
Quando os homens se encontram em reuniões econômicas ou irmandades de sangue, em comunidades de culto ou bandos de assaltantes, isso é sempre o resultado das necessidades e interesses específicos. Só que, para além desses conteúdos específicos, todas essas formas de sociação são acompanhadas por um sentimento e por uma satisfação de estar justamente socializado, pelo valor da formação da sociedade enquanto tal. (Simmel, 2006:64)
\end{abstract}

Palco de muitas interações, "a feira resiste imersa em campo de atritos entre diferentes segmentos sociais e a partir da relação entre mudanças e continuidades, engendrando novas estratégias de sobrevivência” (Pizzignaco, 2016:73).

É o que discutiremos na sequência.

\title{
Reinventando tradições, construindo possibilidades
}

Com o processo de modernização da cidade de Campina Grande, a Feira Central caminhou lado a lado com tais transformações, ora resistindo ao novo, ora incorporando-o. $\mathrm{O}$ advento dos supermercados, dos hipermercados, mas também dos mercadinhos nos bairros fizeram frente à Feira Central, exigindo dos comerciantes ali situados adaptações às influências que a modernidade impôs. A aceitação de cartão de 
crédito por parte de muitos comerciantes e a divulgação e venda de produtos através de plataformas em redes digitais, a exemplo de Instagram e Whatsap são algumas dessas inovações, bem como delivery de mercadorias através de moto-táxi.

A feira de Campina Grande acompanhou toda a história da cidade, adaptando-se ao advento dos diversos meios que se sucederam. Conservando elementos dos meios pretéritos, ao mesmo tempo em que absorvia as modernidades dos meios emergentes (Costa, 2003: 95).

Entre muitos feirantes encontramos pontos convergentes quanto às transformações sofridas pela feira. A maioria deles aponta a presença dos supermercados como principal fator de diminuição dos frequentadores da feira. A fala da interlocutora Salete ${ }^{9}$ mostra como feira e cidade intercambiam transformações.

eu não vou dizer a você que foi o supermercado. Eu vou dizer que foi o progresso. Por quê? Porque antigamente só existia a feira, tudo era comercializado aqui, só que nós fomos crescendo, as pessoas foram crescendo, foram constituindo família, foram sentindo a necessidade de ter algo mais perto, tá entendendo? Então, esses comércios foram invadindo os bairros, os supermercados, então é isso, não é totalmente supermercados. Vou dizer a você que foi um progresso.

A precária acessibilidade é uma dificuldade apontada como empecilho para que mais pessoas frequentem a feira.

Não tem estacionamento, tem aquele estacionamento ali mas é particular, não tem onde você estacionar carga, você para um instante fila dupla lá vem multa, para lá do outro lado lá vem multa, onde você para aqui o cara chega e multa você, a gente num tem estacionamento aqui nessa feira. (Sandra)

Mesmo tendo uma feira de flores, nem tudo são rosas no dia a dia de feirantes e fregueses. A feira "levanta cedo, estende sua rotina nas barracas, defuma com café, alimenta os habitantes com buchada" (Pizzignaco, 2016: 15). O trabalho dos primeiros é

9 Os nomes dos interlocutores aqui aparecem através de pseudônimos. 
árduo, as disputas entre comerciantes por causa de bancas que são adiantadas para ganhar mais espaço e chamar atenção dos clientes, carroças de mão que roçam pernas de fregueses enquanto os carroceiros seguem seus trajetos. A foto a seguir mostra bem o cenário cotidiano na Feira Central.

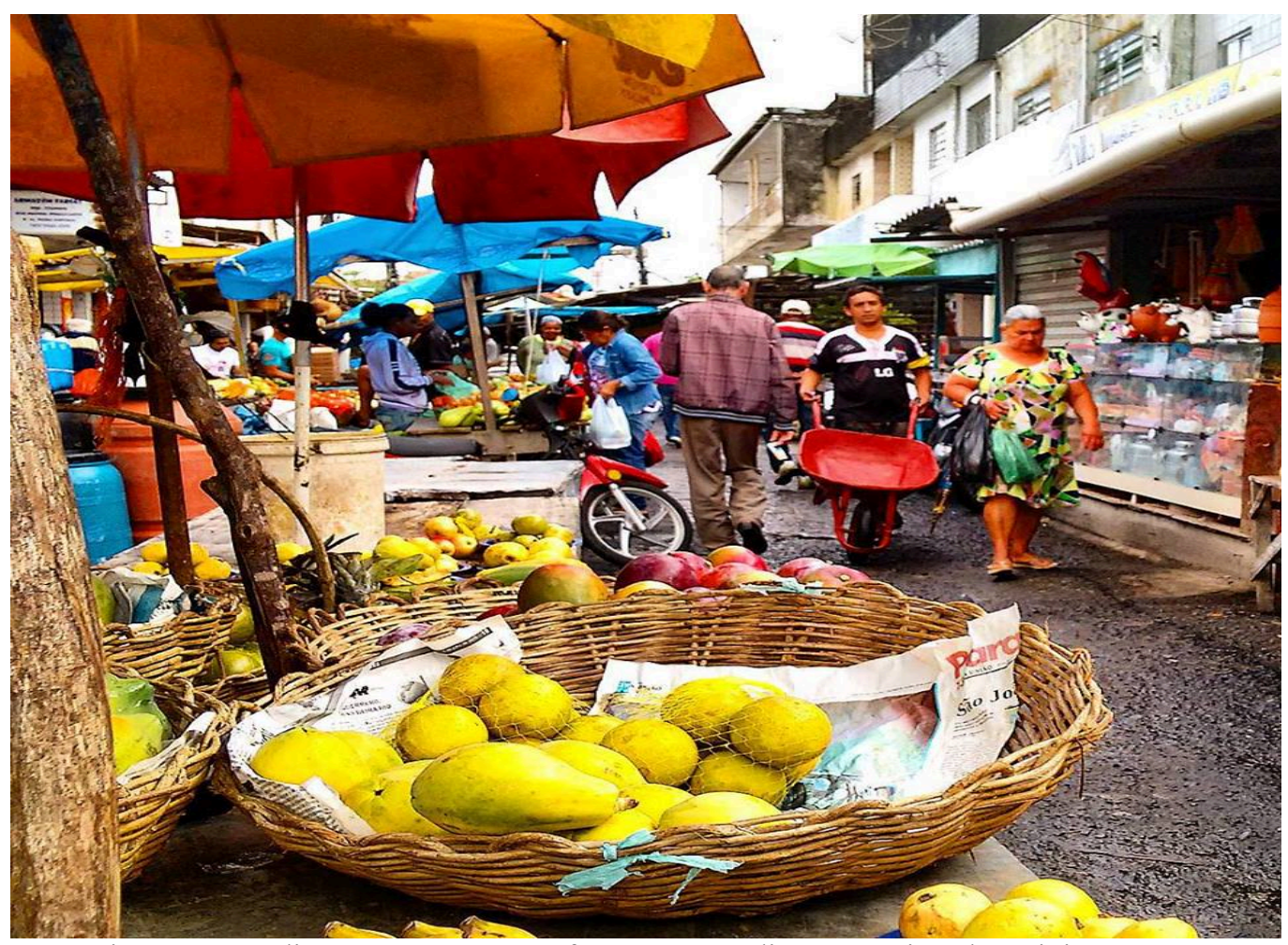

Carroceiros e motos disputam espaço com fregueses. Créditos: Franciscarlos Diniz

É nesse universo relacional que os laços de sociabilidade vão se estreitando, resistindo junto às mudanças modernizantes. A Feira Central tem sido relativamente fixa nos últimos noventa anos, mas seus fluxos relacionais são perenes e através deles os feirantes e fregueses se reinventam dia após dia. Suas práticas não são apenas resistência ao moderno, são também formas de inventá-lo de modo singular.

O feirante Benício atenta bem para a capacidade da Feira Central em se refazer, se reinventar permanentemente, atualizando-se para fazer frente aos desafios colocados por outros setores do comércio localizados na zona comercial do centro da cidade, situada a poucas dezenas de metros da feira.

Antes você só encontrava mais produto de feira mesmo, aqui. Tipo, coisa de utilidade e gênero alimentício, se você viesse uns anos atrás, você não ia ver essa parte de eletrônico. Você consegue comprar de tudo aqui que tem no shopping dos camelôs, é só você procurar. E antes não tinha, antes tudo que você quisesse nessa parte de eletrônico você tinha que migrar lá pro comércio lá de cima, hoje, você 
consegue consertar um celular, consegue consertar um utensílio doméstico e fazer compra de tudo aqui.

Tal como uma lagarta que fica aparentemente imóvel durante seu processo de transformação, até aparecer "subitamente" em forma de crisálida, a Feira Central se metamorfoseia há mais de um século. A feira tem essa metamorfose que quando você pensa que ela tá morta, mas ela não
tá não. É, e é muito cultural, o povo gosta de vir pra feira mesmo, não tem esse
negócio não, você pode morar no Cinza, pode morar num canto longe, tem aquela
cultura de vir à feira, nem que seja para comprar um saco de laranja (Benício).

Nos dias e horários nos quais o movimento de fregueses é pequeno, as interações entre os feirantes ganham outras formas de interação, entre elas os jogos, que acontecem nas ruas, nos corredores entre os bancos e bancas da Feira Central. Ali se pratica jogos de damas, baralho e dominó. E essa forma de interação não é gratuita, pois ela "é uma função significante, isto é, encerra um determinado sentido. No jogo existe alguma coisa em 'jogo' que transcende as necessidades imediatas da vida e confere um sentido à ação" (Huizinga, 2014:3-4).

Há ainda, evidentemente, os que se dedicam à leitura de livros religiosos, que leem mensagens nos seus smartphones etc.

Assim como as relações estabelecidas na Feira Central não se reduzem às interações comerciais entre feirantes e fregueses, os personagens ali presentes também não se limitam a essa dupla de personagens.

Quando a "noite cai", a feira diminui seu fluxo de pessoas e, por conseguinte as sociabilidades, mas ela não fecha, homens e mulheres bebem, comem, conversam, se divertem nos restaurantes e bordeis; andarilhos seguem seus mapas pelas ruas, becos e vielas da feira; homens descarregam mercadorias; outros as carregam para alhures. Esses e outros personagens não estão ausentes durante a jornada diária sob a luz do sol. Ao contrário, muitos estão por ali desde que os primeiros raios de sol começam a iluminar o pavimento das ruas ao amanhecer. À noite, quando as luzes elétricas impõem suas claridades é como se um novo ato de uma peça teatral tivesse início e as centralidades das ações recaíssem sobre esses personagens que 'curiosamente' permanecem invisíveis para muitos durante o dia. A saga desses personagens que 
imprecisamente chamaremos de "noturnos" talvez sirva para reforçar a ideia de pensar a feira como "mangue social", na medida em que também ela, tal como a cidade da qual é um substrato, produz e dá assento a uma multiplicidade de sujeitos sociais que circulam e se localizam nesse lócus de acordo com os lugares que ocupam no seio das relações, cuja valorização social depende da "proximidade" das luzes ou da "distância" dessas, o que faz com que sejam visíveis ou socialmente invisíveis.

A Feira Central é lugar de convivência, de sociabilidades, de encontros e de desencontros, de convergências e divergências. Ela é um mosaico de espaços de interações, onde as relações estabelecidas entre tempo, agentes sociais e processos, concorrem para que a vida na cidade que lhe dá existência produza diversidade e riqueza de possibilidades, de rituais, comportamentos, normas e limites de uso e apropriação do lócus urbano, do qual a feira faz parte.

\section{Considerações finais}

As relações estabelecidas na Feira Central de Campina Grande fazem dela uma caixa de ressonância da metrópole campinense. Ela é um mangue social, que alimenta e se alimenta das "matérias" que tornam a vida possível na cidade metropolitana. Tais relações não se resumem às compras e vendas, pois as formas de interação são complexas, inusitadas e refletem movimentos e conflitos presentes no dia a dia da cidade.

A feira se revela pela percepção das emoções e sentimentos que estão expressos na vivência do lugar. Nela encontramos utopias, esperanças, desejos, insegurança e medos sendo partilhados no seu cotidiano de maneira individual e coletiva.

A feira, tal como a cidade, é lugar vivo, animado pelos sentidos e práticas que seus atores estabelecem nas relações de familiaridade, de jocosidades, de compra, venda e troca, e tantas outras formas de interação.

A Feira Central se revela nas práticas de interação que cotidianamente vêm à luz sob sol e chuva, nas oito ruas que abrigam tantas possibilidades, em pleno coração da pretensiosa metrópole tropical, onde seus personagens, feirantes e fregueses, aqui colocados em destaque, se constroem em interações dialéticas e cotidianas. 


\section{REFERÊNCIAS}

AGIER, Michel. Encontros etnográficos. Interação, contexto, comparação. $1^{\mathrm{a}} \mathrm{Ed}$, São Paulo, Editora EDUSP, Alagoas, Edufal, 2015.

ALBUQUERQUE JÚNIOR, Durval Muniz. A Feira dos Mitos. A fabricação do folclore e da cultura popular (nordeste 1920-1950). São Paulo, Intermeios, 2013.

ARAÚJO, Giovanna de Aquino Fonseca. As feiras livres nortistas portuguesas e nordestinas brasileiras como lócus de trabalho, e de bens simbólicos na contemporaneidade in Anais do IV Congresso Internacional de História, Maringá-PR. Set. 2009a . Disponível em

http://www.pph.uem.br/cih/anais/trabalhos/460.pdf. acesso em 25/08/2017.

ARAÚJO, Giovanna de Aquino Fonseca. Memória e oralidades dos feirantes lusobrasileiros sobre seu respectivo lócus de trabalho diário: aspectos de identificação e valores concebidos por esses sujeitos na contemporaneidade. Anais da ANPUH - XXV Simpósio Nacional de História - Fortaleza, 2009b. Disponível em http://anais.anpuh.org/wp-content/uploads/mp/pdf/ANPUH.S25.0741.pdf. acesso em 25/08/2017.

ARAÚJO, Giovanna de Aquino Fonseca. Requalificação espacial e elaboração de Inventário imaterial: duas experiências em andamento na centenária Feira Central de Campina Grande-PB. VI Congresso Internacional de História. Set. 2013. Disponível em http://www.cih.uem.br/anais/2013/trabalhos/475 trabaljo.pdf acesso em 25/08/2017.

ARAÚJO, Giovanna de Aquino Fonseca. Trajetória histórica conceitual sobre patrimônio imaterial e Cultural no Brasil e em Portugal tendo as Feiras 1 como lugar de investigação. XXVII Simpósio nacional de história, Natal, julho 2013.Disponível http://www.snh2013.anpuh.org/resources/anais/27/1364700080_ARQUIVO textocomp leto.pdfacesso em 25/08/2107. 
BARBOSA, Maicon. Narrativas, conversações e alguns ritornelos em meio à feira livre. Ponto Urbe [online]. 2011. http://journals.openedition.org/pontourbe/1766. Acesso em maio de 2020.

BERGER, Peter \& LUCKMANN, Thomas. A Construção Social da Realidade. $11^{\mathrm{a}} \mathrm{ed}$., Petrópolis, Editora Vozes, 1994. (Col. Antropologia 5)

BLUMER, Herbert. A Sociedade como interação simbólica in COELHO, Maria Claudia (Organização) Estudos sobre interação: textos escolhidos. Rio de Janeiro, EDUEJ, 2013. pp. 75-90.

BOURDIEU, Pierre. O Poder Simbólic. Rio de Janeiro, Bertrand Brasil,1998.

CARLOS, Ana F. O espaço urbano: novos escritos sobre a cidade. São Paulo, contexto, 2004.

CERTEAU, Michel. A Invenção do Cotidiano 1. Artes de fazer. Petropolis, Vozes,1998. CHAUÍ, Marilena. Brasil. Mito fundador e sociedade autoritária. São Paulo, Editora Perseu Abramo, 2000.

COSTA, Antônio Albuquerque da. Sucessões e coexistências do espaço campinense na sua inserção ao meio técnico-científico-informacional : a feira de Campina Grande na interface desse processo (dissertação), UFPE 2003.

DANTAS, Geovany Pachelly Galdino. "Feiras no nordeste". Revista mercator, fortaleza, 2008, v. $7, \quad$ n. $13 . \quad$ Disponível em http://www.mercator.ufc.br/index.php/mercator/article/view/11/7. Acesso em outubro de 2017.

FRÚGOLI Junior, Heitor. Sociabilidade urbana. Rio de Janeiro, Jorge Zahar ed, 2007.

GUIMARÃES. Camila Audi. Feira livre na celebração da cultura popular. 2010. 20p. Trabalho de conclusão de curso. São Paulo: USP. Disponível em: http://www.usp.br/celacc/ojs/index.php/blacc/article/view/140 Acesso em jan. 20128. P. 05.

HUIZINGA, Johan. Homo Ludens: jogo como elemento da cultura. São Paulo, Perspectiva, 2012.

LEFEBVRE, Henri. O direito à cidade. São Paulo, Centauro, 2001. 
MASCARENHAS, Gilmar e DOLZANI, Miriam C. S. Feira livre e territorialidade popular e cultura na metrópole contemporânea In: revista eletrônica Ateliê geográfico. Goiania v. 2, n. 2 UFG - IESA agos/2008. p. 72-87.

MINAYO, M. C. S. O desafio do conhecimento: pesquisa qualitativa em saúde. $8^{\circ}$ ed. São Paulo, Hucitec, 2004.

NASCIMENTO, Walkiria do. Etnografia em uma feira livre; o cenário, o dia de feira, os personagens e a sociabilidade. In Etnografias urbanas: espaço imagem e diferença na cidade/ Luciana Maria ribeiro de Oliveira, Marco Aurélio Paz tella (orgs) - João Pessoa: GUETU, 2017, p. 229-271.

OLIVEIRA, Sâmala s. Olha o rapa: os feirantes e as artes do saber fazer cotidiano na feira central de Campina Grande (1970- 1983). Dissertação ( Mestrado em história, centro de humanidades, Universidade Federal de Campina Grande. Campina Grande, 2012.

PESAVENTO, Sandra Jatahy. Cidades visíveis, cidades sensíveis, cidades Imaginárias. In Revista Brasileira de História, vol.27, núm. 53, janeiro-junho, 2007, pp. 11-23 Associação Nacional de História São Paulo, Brasil.

PIZZIGNACO, Mila. Histórias que vos me nordestes: discursos sobre o "popular" em Campina Grande (PB). TCC (Trabalho de conclusão de curso apresentado ao Instituto de Artes da UNESP para a graduação em Bacharelado e Licenciatura em Artes visuais). São Paulo, 2016.

RAMALHO, Maria de Lourdes Nunes. A Feira: o trovado encantado, Campina Grande: EDUEPB, 2011.

SILVA, Valmir Pereira de. Artes de Fazer a Feira: práticas e representações de negociação na Feira Central de Campina Grande. Dissertação de mestrado em Sociologia, UFCG, Campina Grande, 2005.

SIMMEL, Georg. Questões fundamentais da sociologia: indivíduo e sociedade. Rio de Janeiro, Jorg Zahar Ed.,2006.

SIMMEL, Georg. Le conflit. Paris, Éditions Circé, 1995

VEDANA, Viviane. "Fazer a Feira" estudo etnográfico das artes de fazer de feirantes e fregueses da feira livre de Epatur no contexto da paisagem de Porto Alegre. 
Dissertação (Mestrado, programa de pós-graduação em Antropologia social da Universidade Federal do Rio Grande do Sul. Porto Alegre, janeiro de 2004.

VEDANA, Viviane. Fazer a feira e ser feirante: a construção cotidiana do trabalho em mercados de rua no contexto urbano. Horizontes antropológicos, vol. 29 n 39 , Porto alegre Jan/Jun 2013.

VEDANA, Viviane. No mercado tem de tudo que a boca come: estudo antropológico da duração das práticas cotidianas de mercado de rua no urbano contemporâneo. Tese (Doutorado em Antropologia Social) - Instituto de Filosofia e Ciências Humanas, Universidade Federal do Rio Grande do Sul, Porto Alegre, 2008. Disponível em: http://www.ufrgs.br/handle/10183/13338. Acesso em agosto 2017.

Recebido: $26 / 05 / 2020$

Aprovado: 04/09/2020 